\title{
First report of grapevine rupestris vein feathering virus in Pakistan
}

\author{
Madiha Mahmood $^{1} \cdot$ Andrea Gentili $^{2}$ (D) $\cdot$ Shagufta $\mathrm{Naz}^{1} \cdot$ Francesco Faggioli $^{2}$ \\ Received: 3 April 2019 / Accepted: 30 April 2019 / Published online: 13 May 2019 \\ (C) Società Italiana di Patologia Vegetale (S.I.Pa.V.) 2019
}

Keywords Grapevine · GRVFV · Pakistan

Grapevine rupestris vein feathering virus (GRVFV) belongs to the genus Marafivirus, family Tymoviridae. It was first described on a Greek grapevine cv. Sultanina and then reported in America, Europe, China, New Zealand and Korea (Daldoul et al. 2018).

As part of a grapevine virus survey in Pakistan, the presence of GRVFV was investigated in 35 samples of seven autochthonous grapevine cultivars (Toran, Tarasha lal, Kishmish, Shundo Khani, Askari, Speen Lal, Kings Ruby Seeded and Sahibi), collected during the summer 2017 in two districts (Quetta, Mastung and Pishin) of Balochistan province. Plants, all self-rooted, did not show symptoms potentially caused by GRVFV.

The specific identification of GRVFV was performed by RT-PCR using primers $6156 \mathrm{G} / 6600 \mathrm{R}$ (Reynard et al. 2017) and total RNA extracted with the CTAB method. A $445 \mathrm{bp}$ fragment corresponding to the end of the polyprotein gene was amplified from 15 out of 35 samples. The fifteen positive samples belonged to cvs Toran, Kishmish, Shundo Khani (from Quetta district), Tarasha lal (from Mastung district) and Askari (from Pishin district). To confirm RT-PCR results, an amplicon from Toran was cloned and two different sequences were

Andrea Gentili

andrea.gentili@crea.gov.it

1 Department of Biotechnology, Lahore College for Women University, Lahore 54000, Pakistan

2 Council for Agricultural Research and Economics - Research Center for Plant Protection and Certification, Via C.G. Bertero, 22, 00156 Rome, Italy obtained (GenBank accession numbers MK515145 and MK515146). BLASTN analysis confirmed the identity of GRVFV. The two consensus sequences of the Toran isolates shared 85.2 and $85.4 \%$ nt identity with the reference Mauzac isolate from France (NC_034205).

Given the presence of GRVFV in autochthonous cultivars we can assume that the virus was not recently introduced in Pakistan.

To the best of our knowledge, this is the first report of GRVFV infecting grapevine in Pakistan.

\section{References}

Daldoul et al., 2018. https://doi.org/10.1094/PDIS-03-18-0533-PDN Reynard, J. S., et al. 2017. Plant Dis 101:1062. https://doi.org/10.1094/ PDIS-01-17-0140-PDN [Abstract] [Google Scholar]

Publisher's note Springer Nature remains neutral with regard to jurisdictional claims in published maps and institutional affiliations. 